\title{
Reference book indexes reviewed
}

\section{Catherine Sassen}

The author reports on a study of the frequency and nature of remarks about indexes found in reviews of reference books during the first six months of 2009. Only 28.66 percent of the reviews included evaluative comments about indexes.

\section{Introduction}

An index is considered a significant part of any nonfiction book. However, its importance in a reference work is crucial (Cassell and Hiremath, 2009: 294; Ford, 2008: 28; Katz, 2002, v.1: 28; Nolan, 1999: 68; Perez, 2004: 65; Spiller, 1986: 73; Stevens, 1987: 15; Sweetland, 2001: 104). Jovian Lang (1987: 62) made this point very succinctly when he wrote, 'Most essential in any reference tool is the index.'

It follows that book reviews of reference works should include evaluative comments about their indexes. J. D. Hendry (1986: 23) wrote that indexing should be mentioned in book reviews because an index affects how a book may be used by its reader. Other authors have stated that indexes should be discussed as a means of providing feedback to publishers and of improving indexing practices (Brightman, 1949: 126; Gardner, 1981: 22; Rettig, 1987: 29; Sweetland, 2001: 143). Although these authors have made a good case, how often is their advice followed? How much evaluative information about indexes is provided in reference book reviews?

\section{Literature review}

There have been few systematic studies of these issues. Lipetz (1989: 117) examined reviews of nonfiction books in the New York Times Book Review over ten months and found only three that mentioned indexing. Lavell (1990: 60) studied reviews of 66 books in Archaeological Journal and found only eight mentions of indexing. McFadden (1993: 4-5) analyzed 206 reviews in Choice in 1988 and 1989: 57 mentioned indexing, and 40 included mostly very brief evaluative comments. Dartnell (2007: 186) examined 326 reviews in 11 scientific journals: 54 included comments on indexing, only 34 of which were evaluative.

\section{Methodology}

My aim was to analyze remarks about indexes in reviews of reference books. I chose four journals - Booklist, Choice, Library Journal, and Reference \& User Services Quarterly $(R U S Q)$ - that authors of library reference services textbooks have cited as current sources of book reviews (Bopp and Smith, 2001: 317; Cassell and Hiremath, 2009: 339-40; Katz, 2002, v.1: 88-90; Sweetland, 2001: 18-19). (See Table 1 for further details.)
Table I Journals consulted in the study

\begin{tabular}{|c|c|c|}
\hline Journal & ISSN & Target audience \\
\hline Booklist & 0006-7385 & Public librarians, school librarians \\
\hline Choice & $1943-5975$ & $\begin{array}{l}\text { Academic librarians, faculty } \\
\text { members }\end{array}$ \\
\hline Library Journal & $0363-0277$ & $\begin{array}{l}\text { Public librarians, academic } \\
\text { librarians, special librarians }\end{array}$ \\
\hline RUSQ & $1094-9054$ & $\begin{array}{l}\text { Reference librarians, information } \\
\text { specialists, other professionals } \\
\text { involved in user-oriented library } \\
\text { services }\end{array}$ \\
\hline
\end{tabular}

Booklist, from the American Library Association, is intended 'to provide public and school librarians with reviews that help them decide what to buy' (Booklist, 2010). Although each issue includes articles and columns, the emphasis is on reviews. A 'Reference books bulletin' in each issue has reviews of reference books. I accessed it for this study through ProQuest Research Library, a web-based information service.

Choice, from the Association of College and Research Libraries of the American Library Association, is intended for college and university librarians and faculty members (Choice, 2010). It consists mostly of reviews. I accessed it through Choice reviews online.

Library Journal, from Reed Elsevier, is targeted at 'library directors, administrators, and staff in public, academic, and special libraries' (LibraryJournal.com, 2010). Each issue includes articles, news stories, and a large review section. I accessed it online through ProQuest Research Library.

$R U S Q$, from the Reference and User Services Association of the American Library Association, is designed 'to disseminate information of interest to reference librarians, information specialists, and other professionals involved in user-oriented library services' (RUSQ, 2010). Each issue has feature articles, reports, and reviews. Again, I accessed it online through ProQuest Research Library.

I identified and examined 492 reference book reviews appearing in these journals from January through June 2009.

\section{Frequency of comments about indexes}

Evaluative comments were found in 28.66 percent of the reference book reviews. In $R U S Q, 38.3$ percent of all reference book reviews included evaluative comments, followed 
by 35.71 percent in Booklist, 30.41 percent in Choice, and 11.76 percent in Library Journal.

In 48.58 percent of all reviews there were mentions of the existence of an index or descriptions of the types of indexes. In Library Journal, 75.49 percent of all reference book reviews mentioned the presence of indexes, followed by 53.92 percent in Choice, 40.43 percent in $R U S Q$, and 20.63 percent in Booklist.

In 2.03 percent of all reviews the reviewer commented on the absence of any indexes: the incidence ranged from 2.38 percent in Booklist to 1.96 percent in Library Journal.

There was no mention of indexes in 20.73 percent of all reviews: 41.27 percent in Booklist, 21.28 percent in RUSQ, 13.36 percent in Choice, and 10.78 percent in Library Journal. Some reviewers perhaps did not mention indexes because they worked from page proofs lacking indexes (Weinberg, 1991: 214).

These statistics are summarized in Table 2 and Figure 1.

\section{Evaluative comments about indexes}

Table 3 and Figure 2 show the evaluative comments, broken down by category: 24 of them were negative and 141 positive. (Note that some reviews contained more than one category of comment.)

\section{Negative comments}

Most often negative comments claimed that additional indexes were needed. In eight cases reviewers of books that had indexes would have liked to see at least one further index. Here are two examples:

Salem Press: Crime \& punishment in the U.S., ed. Phyllis B. Gerstenfeld (2008, 3 vols.). Rev. by Lisa Powell Williams, RUSQ, 48(3), 2009.

The set of Crime \& Punishment in the U.S. would have been enhanced by a comprehensive index in each volume rather than the cumulative index in the third volume.

McFarland: Encyclopedia of television shows, 1925 through 2007, by Vincent Terrace (2009, 4 vols.). Rev. by J. M. King, Choice, 46(8), 2009.

All programs are listed alphabetically, and volume 4 features an extensive index. A chronological time line or index of all shows would have made this encyclopedia a stronger candidate for researchers.

Six comments (the second largest category of negative comments) concerned lack of comprehensiveness. For example:

ABC-CLIO: Encyclopedia of the African diaspora: origins, experiences, and culture, ed. Carole B. Davies (2008, 3 vols.). Rev. by Sally Moffitt, RUSQ, 48(3), 2009.

There are, to this reviewer, some curious inclusions and omissions. Why does "Hair" merit an article and "Hairstyles" an index entry but not, for instance, language? Linguistic discussions are included in several articles, "Black/Blackness: Philosophical Considerations" and "Creole, Creolity, Creolization" for example, but there are no entries in the index for language or for linguistics, nor does the encyclopedia contain a separate article on language and language transmission in the Diaspora. Although there are separate articles on gumbo, and the aforementioned jerk seasoning, there is no index entry under food or cookery that would lead the uninitiated to either, nor is there a separate article about cultural food exchanges in the Diaspora. For that matter, the reader unfamiliar with the names of African Diaspora religious systems and practices, such as Candomblé, would be pressed to find articles about them because religion does not figure as a separate article or as a term in the index.

Figure I Reference book reviews and their treatment of indexes

Table 2 Reference book reviews and their treatment of indexes

\begin{tabular}{|c|c|c|c|c|c|c|c|c|c|c|}
\hline & \multicolumn{2}{|c|}{ Booklist } & \multicolumn{2}{|c|}{ Choice } & \multicolumn{2}{|c|}{ Library Journal } & \multicolumn{2}{|l|}{ RUSQ } & $\begin{array}{l}\text { Total } \\
\text { No }\end{array}$ & $\%$ \\
\hline Positive comments & 40 & 31.75 & 54 & 24.88 & II & 10.78 & 14 & 29.79 & 119 & 24.19 \\
\hline Negative comments & 3 & 2.38 & 8 & 3.69 & I & 0.98 & 2 & 4.26 & 14 & 2.85 \\
\hline Positive and negative comments & 2 & 1.59 & 4 & 1.84 & 0 & 0.00 & 2 & 4.26 & 8 & 1.63 \\
\hline Total evaluative comments & 45 & 35.71 & 66 & 30.41 & 12 & 11.76 & 18 & 38.30 & $|4|$ & 28.66 \\
\hline Mention or description & 26 & 20.63 & 117 & 53.92 & 77 & 75.49 & 19 & 40.43 & 239 & 48.58 \\
\hline Notes of absence of indexing & 3 & 2.38 & 5 & 2.30 & 2 & 1.96 & 0 & 0.00 & 10 & 2.03 \\
\hline No comments about indexing & 52 & 41.27 & 29 & 13.36 & $1 \mathrm{I}$ & 10.78 & 10 & 21.28 & 102 & 20.73 \\
\hline Total reviews examined & 126 & 100 & 217 & 100 & 102 & 100 & 47 & 100 & 492 & 100 \\
\hline
\end{tabular}


Table 3 Evaluative comments about indexes in reference book reviews

\begin{tabular}{llcr}
\hline & Negative & Positive & Total \\
Accuracy & & 2 & 2 \\
$\begin{array}{l}\text { Appropriate no. of indexes } \\
\text { Comprehensiveness }\end{array}$ & 8 & & 8 \\
$\begin{array}{l}\text { Conciseness } \\
\text { Cross-references }\end{array}$ & 6 & 23 & 29 \\
$\begin{array}{l}\text { Extensiveness } \\
\text { Formatting of entries }\end{array}$ & 1 & 1 & 1 \\
$\begin{array}{l}\text { Organization } \\
\text { Spelling }\end{array}$ & 2 & 20 & 5 \\
$\begin{array}{l}\text { Thoroughness } \\
\text { Usefulness }\end{array}$ & & 1 & 1 \\
Value judgments & 4 & 35 & 1 \\
Totals & & 43 & 20 \\
\hline
\end{tabular}

Four comments concerned deficiencies in the usefulness or helpfulness of indexes. Here are two examples.

Facts on File: Encyclopedia of American religious history, ed. by Edward L. Queen and others (3rd ed., 2009, 3 vols.). Rev. by Michael Tosko, Booklist, 105(19/20), 2009.

There are both a general index and a synoptic index, although some subjects can be difficult to locate within the set.

Greenwood: American folk songs: a regional encyclopedia, by Norm Cohen (2008, 2 vols.). Rev. by J. E. Druesedow, Jr., Choice, 46(8), 2009.

Unfortunately, some important quick lookups are precluded; e.g., the featured song index does not carry page numbers.

Three comments concerned missing cross-references. For example:

Greenwood: Encyclopedia of scientific principles, laws, and theories, by Robert E. Krebs (2008, 2 vols.). Rev. by David M Fagerstrom, RUSQ, 48(3), 2009.

The alphabetical index is thorough but offers no crossreferencing.

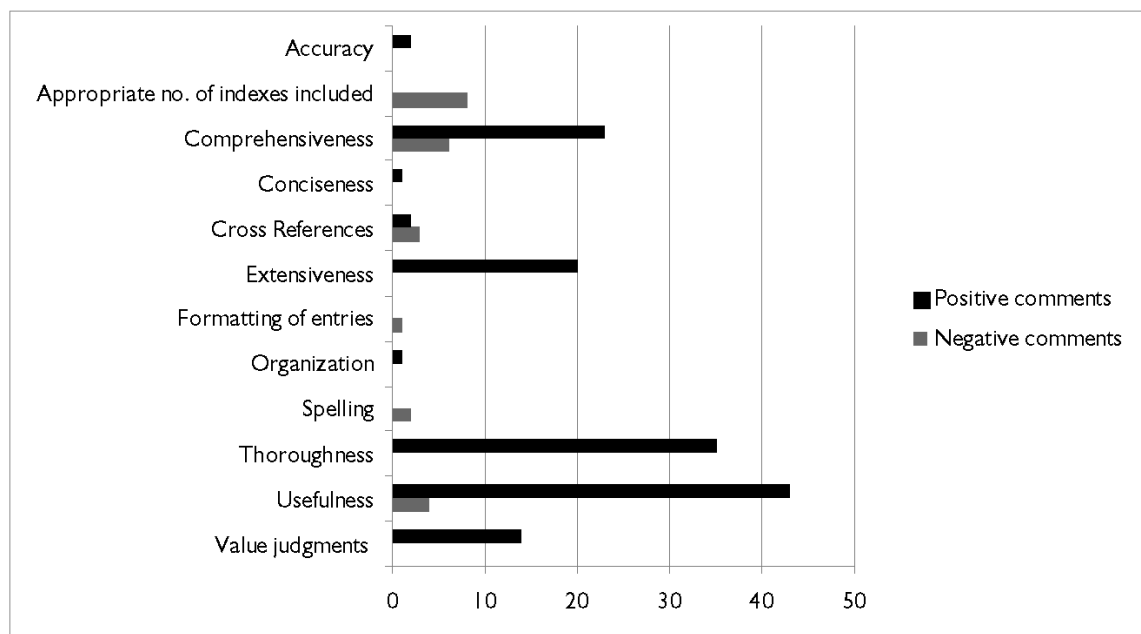

Figure 2
Two comments were about misspelled terms, such as:

Springer Publishing: The professional counselor's desk reference, ed. by Irmo Marini and Mark A. Stebnicki (2009, 1004 pp.). Rev. by K. Condic, Choice, 46(10), 2009.

A minor error is the misspelling of "Myers-Briggs" as "Meyers-Briggs" in the index.

One comment concerned inconsistencies in formatting:

Grey House: Encyclopedia of rural America: the land and people, ed. by Gary A. Goreham (2nd edn., 2008, 2 vols.). Rev. by J. Vance, Choice, 46(6), 2009.

Newly added entries sometimes seem carelessly placed into the alphabetical arrangement and indexing of the first edition (e.g., the new entry on "Water Policy" does not follow the previously established inverted format as with "Policy, Economic").

\section{Positive comments}

There were 141 positive comments, mostly concerning usefulness, thoroughness, and comprehensiveness. Here are two of the 43 about usefulness or helpfulness:

Black Dog and Leventhal: The Encyclopaedia Britannica/ Getty Images history of the world in photographs: 1850 to the present day (2008, 559 pp.). Rev. by Janice Dunham, Library Journal, 134(9), 2009.

The index makes it easy to find any particular image.

People's Medical Publishing House: International standard Chinese-English basic nomenclature of Chinese medicine, ed. by Li Zhen-ji with He Xing-dong and Wang Kui (2008, 789 pp.). Rev. by J. D. Saxton, Choice, 46(8), 2009.

Nine appendixes and seven indexes provide additional information on the literature and history of traditional Chinese and ensure easy access to specific entries.

In 35 comments, indexes were described as thorough, exhaustive, or detailed. For example:

Sterling: Miller's antiques encyclopedia, ed. by Judith Miller (new edn., 2008, 592 pp.). Rev. by Art A. Lichtenstein, Booklist, 105(12), 2009.

A highly detailed 20-plus-page index provides access to individual pieces by artisan, manufacturer, style, name, and place.

Among the 23 comments related to comprehensiveness were:

Gale: Scientific thought: in context, ed. by Brenda W. Lemer and K. L. Lemer (2008, 3 vols.). Rev. by Annette M. Healy, RUSQ, 48(4), 2009.

A comprehensive index in volume 3 allows readers to locate secondary topics and persons mentioned in specific essays. 
Greenwood: Books and beyond: the Greenwood encyclopedia of new American reading, ed. by Kenneth Womack (2008, 4 vols.). Rev. by Sara Rofofsky Marcus, Library Journal, 134(1), 2009.

The comprehensive index covers authors, award types, titles, themes, and genres.

And among the 20 comments on extensive or lengthy indexes:

Sage: Encyclopedia of education law, ed. by Charles J. Russo (2008, 2 vols.). Rev. by Lesley Farmer, Booklist, 105(12), 2009.

An extensive index with many subtopics concludes the second volume.

In 14 cases, value judgments such as 'good' or 'excellent' were given, for example:

Wiley: The encyclopedia of psychological trauma, ed. by Gilbert Reyes and others (2008, 720 pp.). Rev. by Hazel Cameron, Library Journal, 134(3), 2009.

The volume allows systematic access to topics through its alphabetic arrangement and an excellent subject and author index.

Two reviews included positive comments about crossreferences, such as:

Greenwood: Icons of crime fighting: relentless pursuers of justice, ed. by Jeffrey B. Bumgarner (2008, 2 vols.). Rev. by Kristen Mastel, Booklist, 105(15), 2009.

Intriguing, detailed entries along with a 21-page selected bibliography and thorough cross-references in the index make this an excellent reference book for criminal justice and American history students.

In many cases the indexes were described very succinctly with little explanation. This was true of the four comments not classified above: two indexes were described as accurate, one as concise, and one as well organized.

\section{Discussion}

Since an index is an essential part of a reference book, it is disappointing that 20.73 percent of all reviews studied included no mention of indexes. Perhaps some reviewers only had access to page proofs without indexes. It has been argued that indexers should try to persuade publishers to avoid this practice, but it is doubtful that publishers would change their ways. Time is of the essence when books are released, and publishers need books reviewed as quickly as possible.

It also is disappointing that only 28.66 percent of the book reviews examined in this study included evaluative remarks about indexes. Obviously, the reviewers were not required to evaluate the indexes. It has been argued that indexers should encourage book review editors to require evaluative comments about indexes. However, it seems unlikely that editors would appreciate being told how to perform their work, especially by a group with a vested interest. Protests would be more likely to be taken seriously if they came from the targeted readership of the journals in question.

\section{References}

Booklist (2010) What is Booklist? [online] http://www. bookl iston 1 ine. com/help. aspx?page=aboutoat\&pid $=1722793$ \# Q: What is (accessed January 10, 2010).

Bopp $\bar{p}, \bar{R}$. E. and Smith, L. C. (2001) Reference and information services: an introduction, 3rd edn. Englewood, Colo.: Libraries Unlimited.

Brightman, R. (1949) The reviewing of scientific and technical books: some first principles from the point of view of the reader. Aslib Proceedings 1(2), 126.

Cassell, K. A. and Hiremath, U. (2009) Reference and information services in the 21st century: an introduction, 2nd edn. New York: Neal-Schuman.

Choice (2010) [online] http://www.ala.org/ala/mgrps/divs/ $\mathrm{acrl} / \mathrm{publ}$ ications/choice/index.cfm (accessed January 10, 2010).

Dartnell, J. (2007) Scientific book reviews: how much do indexes matter? The Indexer 25(3), 186.

Ford, C. (2008) Crash course in reference. Westport, Conn.: Libraries Unlimited.

Gardner, R. K. (1981) Library collections: their origin, selection and development. New York: McGraw-Hill.

Hendry, J. D. (1986) The administrative role of the book review editor, in Reviews and reviewing: a guide, ed. A. J. Walford. Phoenix, Ariz.: Oryx Press.

Katz, W. A. (2002) Introduction to reference work, 8th edn. Boston, Mass.: McGraw-Hill.

Lang, J. (1987) Evaluation of reference sources published or to be published. The Reference Librarian 6(15), 55-64.

Lavell, C. (1990) Indexes, mentions of, by reviewers. The Indexer 17(1), 60.

LibraryJournal.com (2010) About us [online] http://www.1ibraryjournal . com/info/CA6424872.html (accessed January 10, 2010).

Lipetz, B.-A. (1989) The usefulness of indexes. In Indexing: The state of our knowledge and the state of our ignorance, ed. B. Hass Weinberg. Medford, N.J.: Learned Information.

McFadden, T. (1993) Book reviewers and indexes. Key Words 1(8), 4-5.

Nolan, C. W. (1999) Managing the reference collection. Chicago: American Library Association.

Perez, A. J. (ed.) (2004) Reference collection development: a manual. Chicago: Reference and User Services Association, American Library Association.

Rettig, J. (1987) The reference reviewer's responsibilities. The Reference Librarian 6(15), 21-33.

RUSQ (2010) RUSQ [online] http://www.rusq.org/ (accessed January 10, 2010).

Spiller, D.(1986) Book selection: an introduction to principles and practice, 4th edn. New York: Clive Bingley.

Stevens, N. (1987) Evaluating reference books in theory and practice. The Reference Librarian 6(15), 9-19.

Sweetland, J. H. (2001) Fundamental reference sources, 3rd edn. Chicago: American Library Association.

Weinberg, B. Hass (1991) Indexes and book reviews. The Indexer 17(3), 214.

Catherine Sassen is principal catalog librarian at the University of North Texas. Email: Catherine.Sassencunt.edu 
Copyright of Indexer is the property of Society of Indexers and its content may not be copied or emailed to multiple sites or posted to a listserv without the copyright holder's express written permission. However, users may print, download, or email articles for individual use. 